頸髄損傷患者のADLについて

別府リハビリ・センター

山本喜昭

On the ADL of the Patients with Cervical Cord Injury

By

\title{
Y. Yamamoto
}

Orthopedic Surgery, Beppu Rehabilitation Centre, Beppu.

ADL of twenty-three Pattents (male: 17, female: 6) with cervical spinal cord injury were reported.

The nine cases were achived on independence of ADL. And others were not achived.

The blockade factors were high level of paralytic cervical spinal cord, muscular strength, body weight, incontinence of urine and advanced age.

は じめに

従来わが国においては欧来に比して，脊䯣損傷の中 で頸䯣損傷や胸䯣上位損傷は少ないとされていた. と
ころが昭和 46 年頃より 頸䯣損傷の増加する傾向が み られるようになった1).

当院において昭和 48 年 4 月の開院より昭和 52 年 8 月の間で入院患者 513 例中脊䯣損傷患者は 46 例 で あ

表 1 症

\begin{tabular}{|c|c|c|c|c|c|c|c|c|c|c|c|c|c|c|c|}
\hline \multirow[b]{2}{*}{$\begin{array}{l}\text { 症 } \\
\text { 例 }\end{array}$} & \multirow[b]{2}{*}{$\begin{array}{l}\text { 受傷 } \\
\text { 年 }\end{array}$} & \multirow[b]{2}{*}{ 性 } & \multirow[b]{2}{*}{ 原 } & \multirow[b]{2}{*}{ 骨 傷 } & \multirow[b]{2}{*}{$\begin{array}{l}\text { 残存 } \\
\text { 高位 }\end{array}$} & \multirow{2}{*}{$\begin{array}{ll}\text { 来院ま } \\
\text { での期 } \\
\text { 間 } & \\
\text { 年 } & \text { 月 }\end{array}$} & \multirow{2}{*}{$\begin{array}{l}\text { 入院 } \\
\text { 期間 }\end{array}$} & \multirow{2}{*}{$\begin{array}{l}\text { 尿 } \\
\text { 失 } \\
\text { 禁 }\end{array}$} & \multirow{2}{*}{$\begin{array}{l}\text { 下肢 } \\
\text { 運動 } \\
\text { 麻症 }\end{array}$} & \multicolumn{2}{|r|}{ A } & \multicolumn{2}{|c|}{ D } & $\mathrm{L}$ & \multirow[b]{2}{*}{ 転 㷌 } \\
\hline & & & & & & & & & & $\begin{array}{l}\text { 食 } \\
\text { 事 }\end{array}$ & $\begin{array}{l}\text { 更 } \\
\text { 衣 }\end{array}$ & $\begin{array}{l}r \\
1 \\
v\end{array}$ & $\begin{array}{l}\text { 起 } \\
\text { 坐 }\end{array}$ & $\begin{array}{c}\text { ベット } \\
\downarrow \\
\text { W } \\
\text { C }\end{array}$ & \\
\hline 1 & 28 & $\hat{o}$ & 自 & 5 骨折 & 5 & 2. 10 & 6 & 有 & 完全 & $\triangle$ & $x$ & $x$ & $x$ & $x$ & 転 \\
\hline 2 & 52 & " & 車 & 7 脱臼 & 6 & & & $"$ & 不全 & 0 & $x$ & $\triangle$ & 0 & $\triangle$ & 家 \\
\hline 3 & 30 & $"$ & 土 & 5 脱臼 & 5 & 7. 4 & 2. 5 & " & 完全 & 0 & $x$ & $x$ & $x$ & $x$ & 転 \\
\hline 4 & 47 & 우 & 自 & な し & 6 & 2. 11 & 1. 1 & " & $"$ & 0 & $x$ & $x$ & $x$ & $x$ & 施 設 \\
\hline 5 & 33 & " & 車 & " & 7 & 6 & 9 & " & " & 0 & $\triangle$ & $x$ & $\triangle$ & $x$ & " \\
\hline 6 & 59 & $\hat{\delta}$ & 自 & 7 脱臼 & 7 & & 1. 9 & " & " & 0 & $\bar{x}$ & $\times$ & $\triangle$ & $\triangle$ & 家 庭 \\
\hline 7 & 62 & " & 自 & な し & 左 6 & 2. 1 & 1. & なし & 不全 & 0 & $x$ & $\triangle$ & $\triangle$ & $\triangle$ & "I \\
\hline 8 & 19 & " & 単 & $" \prime$ & 6 & " & & 有 & 完全 & 0 & $x$ & $x$ & $x$ & $x$ & " \\
\hline 9 & 43 & " & 鉄 板 落 † & 6 骨折 & 7 & 1. & 1. & $"$ & $" 1$ & $\triangle$ & $x$ & $x$ & $x$ & $x$ & \\
\hline 10 & 46 & 우 & バケッ落下 & な し & 6 & 3. 6 & 8 & " & " & 0 & $x$ & $x$ & $\triangle$ & $x$ & 当 \\
\hline 11 & 25 & $\hat{\delta}$ & 自 & 5 骨折 & 5 & 2. 9 & 3 & " & " & 0 & $x$ & $x$ & $x$ & $x$ & ג \\
\hline 12 & 50 & 우 & 車 & 5 脱臼 & 5 & 2. 11 & 3 & $" \prime$ & " & $x$ & $x$ & $x$ & $x$ & $x$ & 院 \\
\hline 13 & 17 & " & & な し & 6 & 1. 4 & & なし & " & 0 & $x$ & $x$ & $\triangle$ & $x$ & 寉 \\
\hline 14 & 56 & $\hat{\delta}$ & 車 & " & 5 & 1. 2 & 11 & " & 不全 & 0 & $x$ & $x$ & $x$ & $x$ & \\
\hline 15 & 15 & " & 車 & 6 骨折 & 6 & 2. 2 & 8 & 有 & 完全 & 0 & 0 & 0 & 0 & 0 & 施 設 \\
\hline 16 & 20 & " & 自 & "I & 7 & 1. 8 & 1. & "1 & "I & 0 & 0 & 0 & 0 & $\mathrm{O}$ & 授産場 \\
\hline 17 & 25 & " & 解 & " & 6 & 11 & 1. 7 & " & " & 0 & 0 & $\triangle$ & $\triangle$ & 0 & 施 設 \\
\hline 18 & 20 & " & 自 & 5 骨折 & 6 & 1. 9 & & " & " & 0 & 0 & 0 & 0 & 0 & 授産場 \\
\hline 19 & 27 & " & 几 & 7 脱臼 & 7 & 5. 9 & 3 & " & " & 0 & 0 & 0 & 0 & 0 & 家 庭 \\
\hline 20 & 27 & " & 水泳とびこる & な し & 7 & 2. 4 & & " & " & 0 & 0 & 0 & 0 & 0 & 授産場 \\
\hline 21 & 41 & " & & " & 7 & 8. 2 & 1. 4 & $" \prime$ & " & 0 & 0 & 0 & 0 & 0 & 転 医 \\
\hline 22 & 55 & " & 単 & " & 7 & 5. 4 & 1. & なし & 不全 & 0 & $\triangle$ & 0 & 0 & 0 & 家 庭 \\
\hline 23 & 28 & 우 & 自 & "I & 右 6 & 2. 1 & 1. 9 & " & " & 0 & $\triangle$ & 0 & 0 & 0 & " \\
\hline
\end{tabular}

$<$ 註> 自：自動車, 単：単車, 車：自転車; $\bigcirc$ : 自立, $X$ : 不能, $\triangle$ : 困難だが可能. 
ったが, 頸䯣損傷患者 23 例となり 全脊䯣損傷患者の 半数に相当する. そこでこれら 23 例について ADL および転帰などについて検討し二，三の知見を得たの で報告する.

\section{1 症例:}

23 例のうち男 17 例，女 6 例之なり，おおよそ 3 : 1 と男が多い. そして受傷年令は 15〜62才で平均年 令 35.8 才なった. 年代別にみると 15〜25才： 7 例，26〜35才： 6 例, 36 45才：2 例，46〜 55才： 5 例, 56 才以上 3 例である.（表 1 )

損傷高位を機能の残存レベルでみると，第 5 頸髄節 残存： 4 例, 第 6 頸䯣節残存: 11 例, 第 7 頸髄節 残 存：8例となった. そして全例上肢に関しては完全運 動麻瘨はみられず，すべて不全麻痺であったが下肢で は 23 例中 18 例が完全麻疸で, ほかの 5 例が不全麻㾝 であった．この 5 例においてあ下肢機能の実用性はみ られなかった。

膀胱障害をみると 23 例中 5 例は 自動膀胱であった が，ほかの 18 例に尿失禁がみられた. 女性の 6 例 中 4 例に尿失禁があり，乙れは $\mathrm{ADL}$ 自立にたいして 重大な阻害因子となった.

受傷原因は自動車：8例, 単車：2 例, 自転車： 5 例，スポーツ：3例，重量物の落下によるもの：2 例, その他： 3 例であった. 自動車事故 8 例中では運 転者之助手席乗車が各 3 例で歩行者が 2 例亡なる.

受傷時より当院へ入院までの期間をみると 2 月〜 8.2 年となる. 年別に分類すると, 1 年末満： 4 例, $1 \sim 2$ 年: 5 例, $2 \sim 3$ 年: 9 例, 3 年以上： 5 例之 なり, 受傷後 $2 \sim 3$ 年経過して来院するあのが多い.

当院入院時における医療保険の種類別をみると国保 : 9 例, 労災: 6 例, 健保： 2 例, 健家： 4 例, 生保 ：2 例となった. そして全例とも身体障害者手帳 1 種 1 級の交付をうけた.

\section{ADL:}

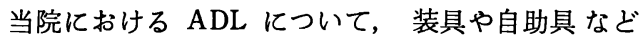
を使用して ${ }^{2)}$ 食事, 更衣, トイレ, 起坐およびベット ほ車椅子動作について検討した.

表 2 にみられるとおり, 食事動作においては装具や 自助具を使用することによって 23 例中 20 例を自立さ せることが出来た. しかし更衣：7例，トイレ：8 例, 起坐：9 例, ベットセ車椅子：9例が自立するに
表 2 A D L 達成結果

\begin{tabular}{|c|c|c|c|c|c|}
\hline & 食事 & 更衣 & トイレ & 起坐 & $\mid \begin{array}{c}\text { ベット } \\
\downarrow \uparrow \\
\text { 車椅子 }\end{array}$ \\
\hline $\begin{array}{lr}\text { 自 } & \text { 立 } \\
\text { 困 } & \text { 難 が 可能 } \\
\text { 能 }\end{array}$ & $\begin{array}{r}20 \\
2 \\
1\end{array}$ & $\begin{array}{r}7 \\
3 \\
13\end{array}$ & $\begin{array}{r}8 \\
3 \\
12\end{array}$ & $\begin{array}{l}9 \\
6 \\
8\end{array}$ & $\begin{array}{r}9 \\
3 \\
11\end{array}$ \\
\hline
\end{tabular}

とどまった. しかし理学療法, 作業療法的アプローチ により, 困難だが可能なものは更衣：3例，トイレ： 3 例, 起坐：6例, ベットせ車椅子： 3 例とすること が出来た. 総合的に判断して ADL 自立 9 例とし, ほ かの 14 例は自立不能とした.

\section{3. 転帰：}

23 例中当院を退院した 17 例の転帰をみると家庭復 㷌： 7 例, 施設： 7 例（授産場 3 , 重度身体障害者更 生授護施設 2 , 療護施設 2), と転医：3 例 となっ た.

転医した 3 例を除く 14 例について受傷時より家庭 または施設のゴールに達するまでの期間についてみる と, 短いあので 1 年 5 力月, 長いあのになると 6 年 4 カ月を要している. 期間別に分類すると 2 年未満： 3 例, $2 \sim 3$ 年: 6 例, $3 \sim 4$ 年: 2 例, 4 年以上: 3 例之なった. 14 例中 9 例の約 $60 \%$ ののが受傷後 3 年以内にゴールに達したことになる.

\section{4. 考察:}

わが国における脊䯣損傷患者の発生率に関して正確 な統計はなされていない現状であるが，昭和 46 年頃 より頸䯣損傷患者の増加が著しいとされている ${ }^{1)}$. 当 院において約 4 年半の間で脊䯣損傷患者 46 例中 頸䯣 損傷患者は 23 例となった. 乙れらの受傷原因をみる 之, 自動車, 単車, 自転車事故によるものが 15 例 と なり, 莖髅損傷の $65 \%$ 交通事故に起因したことに なる. 当院の性格上, 頸䯣損傷患者が多くなることも 考えられるが, 交通事故の多発により頸䯣損傷患者の 増加する傾向がうかがえる.

頸䯣損傷においては麻㾝レベルを知り, 残存機能を 正確に評価することは重要なととである. これら 23 例の残存機能レベルをみると, 第 5 頸䯣節残存 4 例, 第 6 頸䯣節残存 11 例，第 7 頸䯣節残存 8 例となっ た. 当院の施設環境下において, 各種装具や自助具を 使用した上での ADL 達成結果は表 2 にしめすとお りである. この結果より総合的に判断して当院におけ 
るADL 自立 9 例, 自立不能 14 例とした. てれを残 存機能レベルでみると第 5 頸髄節残存の 4 例は全例が 自立不能となり, 第 6 頸䯣節残存では 11 例中 4 例 が 自立そして第 7 頸髄節残存では 8 例中 5 例が自立する にとどまった.

1955 年 Long ら3) は脊髄損傷患者の機能的, 社会 的目標を麻㾝高位に分類し報告しているが，残念なこ とに約 20 年後の 現在においてもそれがよく符合する のである.ただし Long らは第 5 頸戫節残存レベル では食事動作の自立は不能としているのにたいして, 当院では 1 例のみ自立不能とした. これは洋食と和食 の差であり，パンをちぎり肉を切る必要のある 洋食 と，ホークとスプーンを用いればほとんど食事が可能 である和食との違いであろう.

ADL 自立不能とした 14 例の 阻害因子について 検 討すると，第 5 頸䯣節残存は全例が自立できなかった ので麻㾝レベルが最大の阻害因子といえょう．ほかの 10 例についてみる之，筋力 8 例，尿失禁 4 例，痙性 3 例，体重 2 例そして高令 2 例となった．亡くに女性 の尿失禁をみた 4 例は ADL を自立することは不能 であった. これは女性の場合, 完全な収尿器が開発さ

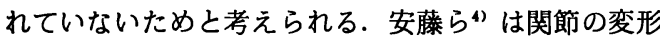
拘縮が重要な阻害因子となったとしているが，当院で はそのような症例はみられなかった。

てのように頸髅損傷においては，同一髄節であ能力 差が著しく認められるが，乙れは損傷の髄節での上下 への広がり，筋の㵦節支配の個人差，耐久性の個人 差，心肺・腸管の合併症や自律神経の合併症の有無な どが関連しているためと考えられる.

これら 23 例中で, 当院を退院した 17 例の転帰をみ ると, 家庭復㷌 7 例, 施設 7 例そして転医 3 例となっ た. 施設の種類は授産場 3 例, 更生援護施設 2 例, 療 護施設 2 例である.なお授産場に入所した 3 例につい ては，当センターにおいて自動車免許を取得させた。 欧米においては頸䯣損傷者の就業が多数報告されてい あが，わが国の現状では困難である.

受傷より最終ゴールまでの期間をみると，短いもの で 1 年 5 力月, 長いもので 6 年 4 力月を要している 長尾5) は医学的リ八は 1 年も継続すると患者の能力は プラトーに達するとしているが，現実には患者の障害
の受容，家庭の環境，受けいれ施設の問題など多くの 障害が考えられる．当院においては家庭と施設に復帰 した 14 例中で約 $60 \%$ に相当する 9 例を受傷より 3 年 以内に最終ゴールにとどけることが出来た.

頸髅損傷患者では病院内で ADL が自立したとし てあ家庭に帰った場合を考えると介助者が必要であ る.たとえば食事一つをとっても，乙れの自立という のは食べるだけであって，食事を作ることは出来な い.すなわち一人では生活出来ないてとである．乙れ にたいして対麻㾝の場合は一人でも自立して生活でき ることが多い，明らかに頸䯣損傷者は胸・腰髅損傷者 より重度の身体障害者と云える，ところが，わが国の 身体障害者等級ではこの両者を同じ 1 級に格づけして いるのである．最重度の障害者である頸随損傷者によ りよい行政的アプローチを求めるためにはまず身障法 の改革が第一だと考える.

結語

（1）頸䯣損傷患者 23 例（今 $17 ，$ ㅇ 6) について ADL などを検討した，当院における ADL で自立 したもの 9 例, 自立不能のあの 14 例となった. ADL の阻害因子としては麻㾝レベル, 筋力, 性, 体重, 座 性，高令などが考えられる。

（2）退院患者 17 例の転帰は 家庭復帰 7 例, 施設 7 例，転医 3 例となった。転医を除く 14 例中 9 例 は 受傷より 3 年以内に最終ゴールに達したことになる.

(3) 身体障害者手帳の等級で最重度の障害者であ る頸損者を特別に格づけする必要がある.

\section{文献}

1）赤津隆：脊䯣損賃の病理と病因論。 リ八医学, 14, 161-162, 1977.

2）原武郎：理学療法作業療法マニュアル。医菌薬 出版, 1972 .

3) Long, C, Lawton E. B.: Functional Significance of spinal cord lesion level Arch. phys. Med. \& Rehabil., 36, 249-255, 1955.

4) 安藤徳彦・他：日常生活動作の訓練効果（頸 損）扰よび日常生活動作評価法の検討. 総合リ 八, $5,579-587,1977$.

5) 長尾竜郎：脊䯣損甥の作業療法. リ八医学. 14, 186-189, 1977. 